\title{
Impacts of an intense wildfire smoke episode on surface radiation, energy and carbon fluxes in southwestern British Columbia, Canada
}

\author{
Ian G. McKendry ${ }^{1}$, Andreas Christen ${ }^{2}$, Sung-Ching Lee ${ }^{1}$, Madison Ferrara ${ }^{1}$, Kevin B. Strawbridge ${ }^{3}$, \\ Norman O'Neill ${ }^{4}$, and Andrew Black ${ }^{5}$ \\ ${ }^{1}$ Department of Geography, The University of British Columbia, Vancouver, Canada \\ ${ }^{2}$ Environmental Meteorology, Faculty of Environment and Natural Resources, \\ University of Freiburg, Freiburg, 79085, Germany \\ ${ }^{3}$ Air Quality Research Division, Environment Canada, 4905 Dufferin St, Toronto, Canada \\ ${ }^{4}$ Centre for Research and Applications in Remote Sensing, Université de Sherbrooke, Sherbrooke, Canada \\ ${ }^{5}$ Faculty of Land and Food Systems, The University of British Columbia, Vancouver, Canada
}

Correspondence: Ian G. McKendry (ian@geog.ubc.ca)

Received: 16 March 2018 - Discussion started: 17 May 2018

Revised: 10 August 2018 - Accepted: 17 December 2018 - Published: 22 January 2019

\begin{abstract}
A short, but severe, wildfire smoke episode in July 2015, with an aerosol optical depth (AOD) approaching 9, is shown to strongly impact radiation budgets across four distinct land-use types (forest, field, urban and wetland). At three of the sites, impacts on the energy balance are also apparent, while the event also appears to elicit an ecosystem response with respect to carbon fluxes at the wetland and a forested site. Greatest impacts on radiation and energy budgets were observed at the forested site where the role of canopy architecture and the complex physiological responses to an increase in diffuse radiation were most important. At the forest site, the arrival of smoke reduced both sensible and latent heat flux substantially but also lowered sensible heat flux more than the latent heat flux. With widespread standing water, and little physiological control on evapotranspiration, the impacts on the partitioning of turbulent fluxes were modest at the wetland compared to the physiologically dominated fluxes at the forested site. Despite the short duration and singular nature of the event, there was some evidence of a diffuse radiation fertilization effect when AOD was near or below 2. With lighter smoke, both the wetland and forested site appeared to show enhanced photosynthetic activity (a greater sink for carbon dioxide). However, with dense smoke, the forested site was a strong carbon source. Given the extensive forest cover in the Pacific Northwest and the growing importance of forest fires in the region, these results suggest
\end{abstract}

that wildfire aerosol during the growing season potentially plays an important role in the regional ecosystem response to smoke and ultimately the carbon budget of the region.

\section{Introduction}

Wildfire activity is projected to increase in frequency and duration over the next century in western North America, primarily as a result of the increased summer temperatures, persistent drought, and reduced snowpack accompanying climate change (IPCC, 2014; Setelle et al., 2014). In addition to the obvious impacts on visibility and air quality, aerosols arising from biomass burning scatter and absorb solar radiation (direct effect) while also influencing cloud processes by acting as cloud condensation nuclei (indirect effect; IPCC, 2014). Furthermore, and of particular focus in this work, recent studies point to significant impacts on surface turbulent and radiative fluxes, boundary layer stability and energetics (including cloud development), and the carbon exchange between biosphere and the atmosphere (Li et al., 2017).

Radiative impacts of biomass burning are well documented in a variety of settings, including South America (Moreira et al., 2017; Sena et al., 2013; Schafer et al., 2002), Africa (Schafer et al., 2002), Spain (Calvo et al., 2010), Rus- 
sia (Chubarova et al., 2012; Pere et al., 2014), North America (Markowicz et al., 2017; Vant-Hull et al., 2005), and Asia (Wang et al., 2007). However, there is growing literature concerned with impacts of smoke plumes on atmospheric boundary layer dynamics as well as surface radiation and energy budgets. For example, Taubman et al. (2004) investigated the impact of a wildfire plume underlain by an urban haze layer in Virginia and Maryland, US, when aerosol optical depth $(\mathrm{AOD})$ at $500 \mathrm{~nm}\left(\tau_{500}\right)$ varied between $0.42 \pm 0.06$ and $1.53 \pm 0.21$. In that case, atmospheric absorption of solar radiation by the smoke and haze layers resulted in net cooling at the surface and heating of the air aloft, thereby increasing stability. Absorption of solar radiation in the dense smoke layer maintained a morning subsidence inversion and thereby created a positive feedback loop preventing vertical mixing and dilution of the smoke plume itself. Wang and Christopher (2006) report a similar broad range of impacts on surface radiation and/or energy budgets and boundary layer dynamics in a modeling study of the impact of Central American biomass burning on the source region as well as the southeastern US (for $\tau_{550}=0.09$ ). At the plant canopy scale, Yamosoe et al. (2006) have focused on the impact of biomass burning aerosol on Amazonian forests and have noted an increase in diffuse radiation within the canopy combined with a reduction in total photosynthetically active radiation (PAR) at the top of the canopy. These impacts affected sensible and latent fluxes as well as net ecosystem exchange (NEE) of carbon dioxide $\left(\mathrm{CO}_{2}\right)$. Subsequently, Steiner et al. (2013) have explored such ecosystem responses using data from six US FLUXNET sites and demonstrate that high AOD reduces midday net radiation by $6 \%-65 \%$ coupled with a $9 \%-$ $30 \%$ decrease in sensible and latent heat fluxes. Niyogi et al. (2004), in an examination of six AmeriFlux sites, conclude that aerosols can exert a significant impact on net $\mathrm{CO}_{2}$ exchange (perhaps more so than clouds), whereby the $\mathrm{CO}_{2}$ sink is increased with aerosol loading for forest and croplands. This effect has become known as the diffuse radiation fertilization effect (DRF), whereby an increase in photosynthesis results from a trade-off between decreased solar radiation and increased light scattering during clouds or smoke (Park et al., 2018, and references therein). It is suggested that the magnitude of the effect is controlled by canopy architecture, leaf area index and plant functional type. Finally, an extensive review of these and other factors (including forest fire aerosols) affecting productivity and carbon fluxes, with a focus on the northern Australian savanna biome, can be found in Kanniah et al. (2010).

In western Canada, previous studies have examined the chemistry and transport of smoke plumes as well as the impacts on local air quality (Cottle et al., 2014; McKendry et al., 2010, 2011). However, to date, the impacts on radiation and energy budgets, boundary layer dynamics, and ecosystems have not been addressed for biomass burning associated with the coastal temperate coniferous forest biome. As the risk of wildfire increases in such areas (Setelle et al., 2014) biomass burning is likely to have non-trivial impacts on surface climates as well as ecosystem productivity and the carbon cycle in Canada's most productive ecozone.

During the summer of 2015, a rare opportunity arose to investigate such impacts under clear skies and for unusually high AOD $\left(\tau_{500} \sim 2.5\right)$. A period of prolonged drought and elevated temperatures resulted in sustained wildfire activity throughout the Pacific Northwest. In early July 2015, a particularly intense event had significant impacts on air quality and visibility in southwestern British Columbia. Ground level hourly $\mathrm{PM}_{2.5}$ (particulate matter less than $2.5 \mu \mathrm{m}$ in diameter) concentrations approached $200 \mu \mathrm{g} \mathrm{m}^{-3}$ in the city of Vancouver on 5 July and were associated with smoke emanating from approximately $150 \mathrm{~km}$ to the northeast in the Pemberton region (Fig. 1). By 7 July reports noted that these Elaho, Boulder Creek, and Nahatlatch fires had spread to a combined area of approximately $30000 \mathrm{ha}$.

In this study, we focus on the impacts of relatively "fresh" smoke ( $\sim 1-2$ days old) from these intense temperate coniferous forest fires on the radiation budget across four distinct land-use types (wetland, an urban residential area, an agricultural grass field, and a coniferous forest) as well as surface energy budgets at three of the sites. Finally, we tentatively (given limitations due to the short duration of the event) explore ecosystem response in terms of carbon fluxes at two of the sites (forest and wetland). In so doing, we add a new geographic setting to the growing catalog of such ecosystem impacts and compare the results with studies from other regions. Furthermore, the availability of sunphotometer and aerosol LiDAR data from the immediate area greatly enriches the information available for interpretation of this event.

\section{Background and data sources}

\subsection{Synoptic overview}

During 2-6 July 2015, western Canada was under the influence of a $500 \mathrm{hPa}$ ridge of high pressure centered off-shore at $135^{\circ} \mathrm{W}$. This resulted in northwesterly upper-level flow across southwestern British Columbia. At the surface, a thermal trough was located along the Western Cordillera, a pattern associated with poor air quality in the region (McKendry, 1994). Vancouver International Airport recorded maximum daily temperatures in the range $25-27^{\circ} \mathrm{C}$ from 2-6 July, with nighttime minima of $21^{\circ} \mathrm{C}$. Skies were generally cloudless with no precipitation recorded, and maximum wind gusts were of $\sim 10 \mathrm{~m} \mathrm{~s}^{-1}$.

Commercial aircraft soundings (Aircraft Meteorological Data Relay - AMDAR) from Vancouver International Airport (YVR) departures and arrivals show development of a strong surface-based inversion late on 4 July that persisted through 5 July 2015 and coincided with smoke arrival midafternoon on 5 July over the western edge of the lower Fraser 


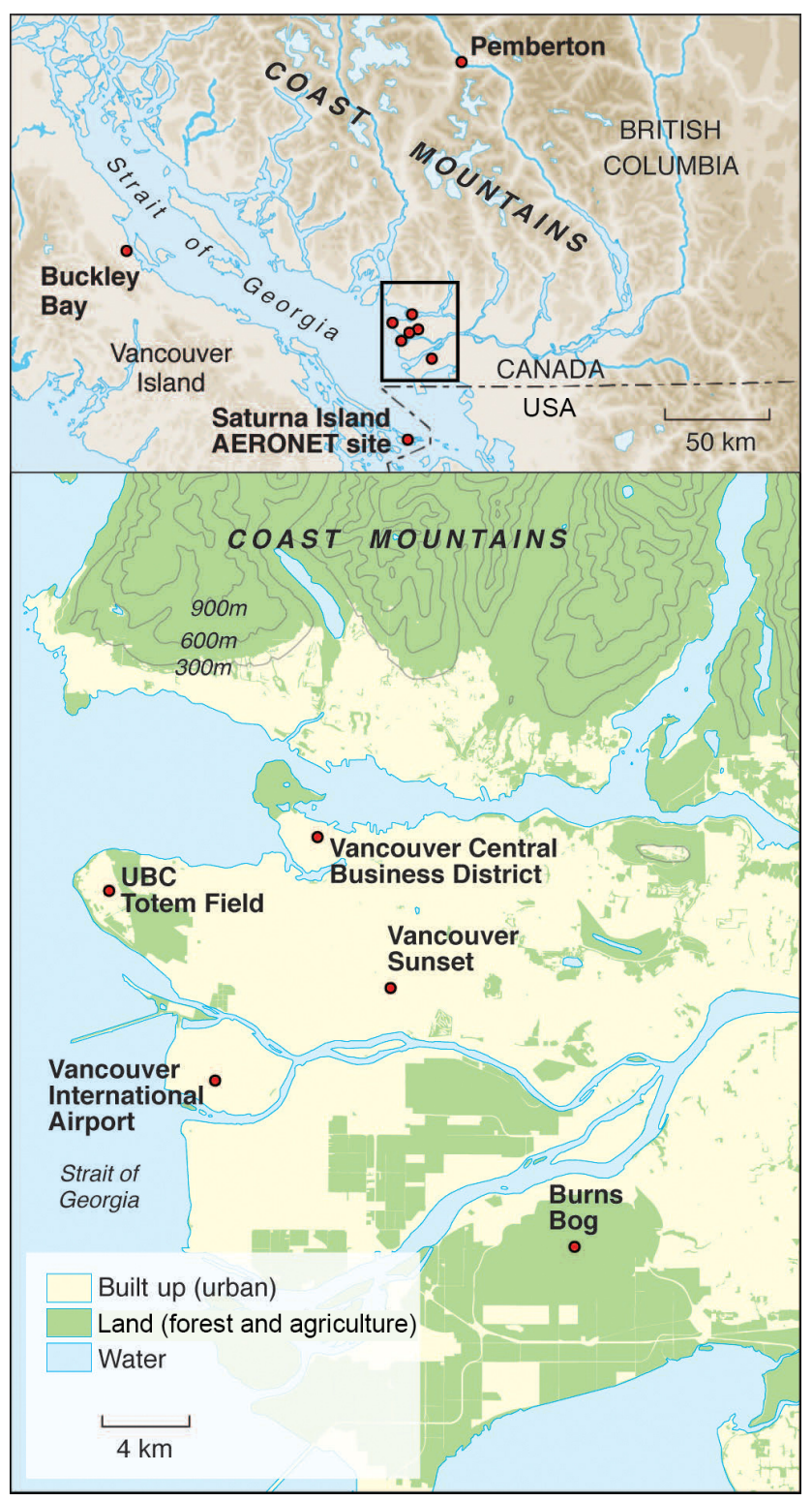

Figure 1. Map with inset showing all places mentioned in text.

Valley (see Supplement). At that time, the inversion top was at $\sim 500 \mathrm{~m}$ above ground and was $\sim 10 \mathrm{~K}$ in magnitude. As shown below, this strong inversion effectively trapped the smoke plume below it and was likely responsible for the high particulate matter concentrations and poor visibility observed on 5 July. By 6 July this capping inversion was no longer present and likely disappeared as a result of the evolving weather pattern and advection.

\subsection{LiDAR}

The Environment Canada UBC LiDAR has operated since 2008 at the University of British Columbia (UBC - Totem Field - see Fig. 1). This remotely controlled facility was housed in a cargo trailer with modifications including a roof hatch assembly, basic meteorological tower, radar interlock system, climate control system, and leveling stabilizers. A Continuum Inlite III (small footprint) laser operating at $1064 / 532 \mathrm{~nm}$ simultaneously, with a pulse repetition rate of $10 \mathrm{~Hz}$, is the foundation of the system. The upward-pointing system measures the return signal in three channels $(1064 \mathrm{~nm}$ and two polarization channels at $532 \mathrm{~nm}$ ). The system is described in detail by Strawbridge (2013), and an example of its application is shown in Cottle et al. (2014).

\subsection{AERONET and AEROCAN}

The global AERONET (Aerosol Robotic Network) has operated since 1993 and is focused on measurements of vertically integrated aerosol properties using the CIMEL sunphotometer and sky radiometer instrument (Holben et al., 1998). AEROCAN CIMELs (AEROCAN is the Canadian sub-network of AERONET) include a facility on Saturna Island, $55 \mathrm{~km}$ to the south of the UBC site. Here, solar irradiances are acquired across eight spectral channels (340, 380, $440,500,670,870,1020$, and $1640 \mathrm{~nm})$ that are transformed into three processing levels of aerosol optical depth (AOD): 1.0 is non-cloud screened, 1.5 is cloud screened, and 2.0 is cloud screened and quality assured. McKendry et al. (2011) demonstrated the application of these data to the transport of California wildfire plumes. In this paper, as in McKendry et al. (2011), the SDA (spectral deconvolution algorithm) was applied to Level 1.0 AOD spectra in order to better delineate the strongly varying contribution of fine-mode smoke particles at a reference wavelength of $500 \mathrm{~nm}$. Level 1.0 input AODs were chosen to minimize "false negative" smokeAOD rejection attributed to the Level 1.5 cloud-screening algorithm.

\subsection{Radiative and turbulent flux data}

The smoke event of July 2015 coincided with a period in which routine long-term measurements of surface radiation and turbulent fluxes (sensible and latent heat using the eddycovariance method) were made at three sites in the region, while at a fourth site only the radiation budget was observed (Table 1). Photographs of the sites, a detailed description of the instrumentation, discussion of instrumental intercomparability, corrections applied, and data manipulations are provided in the Supplement. Turbulent fluxes were corrected for spike removal, density fluctuations (Webb et al., 1980), and sensor separation effects. Data processing at all sites were cross-checked against standardized SMARTFlux processing algorithms (LI-COR Inc.).

Buckley Bay (Ca-Ca3) is a flux tower with eddycovariance and radiation sensors measuring the exchange between a coniferous forest stand (Douglas fir, 27 years old) and the atmosphere. The site is located on the eastern slopes of the Vancouver Island Ranges, about $150 \mathrm{~km}$ to the west 
Table 1. Measurements and site characteristics (bullets indicate measurements).

\begin{tabular}{llcccl}
\hline $\begin{array}{l}\text { Site } \\
\text { land cover }\end{array}$ & FLUXNET ID & Energy budget & Radiation budget & NEE & $\begin{array}{l}\text { Coordinates } \\
\text { (WGS-84) }\end{array}$ \\
\hline $\begin{array}{l}\text { Buckley Bay } \\
\text { coniferous forest }\end{array}$ & Ca-Ca3 & $\bullet$ & $\bullet$ & $\bullet$ & $\begin{array}{l}124^{\circ} 54^{\prime} 1.44^{\prime \prime} \mathrm{W} \\
49^{\circ} 32^{\prime} 4.63^{\prime \prime} \mathrm{N}\end{array}$ \\
\hline $\begin{array}{l}\text { Burns Bog } \\
\text { wetland }\end{array}$ & Ca-DBB & $\bullet$ & $\bullet$ & $\bullet$ & $\begin{array}{l}122^{\circ} 59^{\prime} 5.60^{\prime \prime} \mathrm{W} \\
49^{\circ} 07^{\prime} 45.59^{\prime \prime} \mathrm{N}\end{array}$ \\
\hline $\begin{array}{l}\text { Vancouver UBC } \\
\text { grass }\end{array}$ & - & & & - & $123^{\circ} 14^{\prime} 56.41^{\prime \prime} \mathrm{W}$ \\
\hline $\begin{array}{l}\text { Vancouver Sunset } \\
\text { residential urban }\end{array}$ & $\mathrm{Ca}-\mathrm{VSu}$ & $\bullet$ & $\bullet$ & $129^{\circ} 15^{\prime} 19.50^{\prime \prime} \mathrm{N}$ \\
\hline
\end{tabular}

of Vancouver. Full descriptions of the site and the instruments can be found in Humphreys et al. (2006) and Chen et al. (2009). Burns Bog (Ca-DBB) is a floating platform with eddy-covariance and radiation instrumentation on an open wetland with mosses, sedges, and a significant faction of standing water. Further details of the site are described in Christen et al. (2016) and Lee et al. (2017). Vancouver Sunset $(\mathrm{Ca}-\mathrm{VSu})$ is an urban observational tower above a residential detached urban neighborhood. Details of the instrumentation can be found in Crawford and Christen (2014).

Vancouver UBC is a climate station on the campus of the University of British Columbia that features a full set of radiation measurements.

Based on descriptions and conventions described in Oke (1987), the surface radiation budget can be defined as

$Q^{*}=K_{\downarrow}-K_{\uparrow}+L_{\downarrow}-L_{\uparrow}$,

where $Q^{*}$ is the net all-wave radiation, $K_{\downarrow}$ is the shortwave irradiance comprising direct and diffuse solar radiation, $K_{\uparrow}$ is the reflected shortwave radiation, $L_{\downarrow}$ is the longwave ("thermal") irradiance from the sky, and $L_{\uparrow}$ is the longwave radiation emitted and reflected from the surface (all in $\mathrm{W} \mathrm{m}^{-2}$ ).

The ratio $K_{\uparrow} / K_{\downarrow}$ is the surface albedo $(\alpha)$ and is the shortwave reflectance of the surface in the solar band. $K_{\text {ext }}$ is the extraterrestrial solar radiation and represents the flux density of solar radiation falling at the outer edge of atmosphere and is computed based on date, time, and latitude at the site. The ratio of $K_{\downarrow} / K_{\text {ext }}$ is a measure of the bulk transmissivity of the atmosphere to shortwave radiation. PAR, measured at Burns Bog only, is shortwave radiation in the range $440-670 \mathrm{~nm}$ and is typically expressed in terms of photon flux density $\left(\mu \mathrm{mol} \mathrm{m}{ }^{-2} \mathrm{~s}^{-1}\right)$.

Furthermore, the non-radiative partitioning of energy partitioning over a surface can be defined in three dimensions using the surface energy balance (Oke et al., 2017):

$Q^{*}+Q_{\mathrm{F}}=Q_{\mathrm{H}}+Q_{\mathrm{E}}+Q_{\mathrm{G}}+Q_{\mathrm{S}}+Q_{\mathrm{A}}$, where $Q_{\mathrm{F}}$ is the heat released inside a volume due to human activities (anthropogenic heat flux), $Q_{\mathrm{H}}$ is the turbulent (convective) sensible heat flux to the atmosphere, $Q_{\mathrm{E}}$ is the turbulent (convective) latent heat exchange with the atmosphere (including evaporation and transpiration), $Q_{\mathrm{G}}$ is the conductive exchange of energy with the underlying substrate, $Q_{\mathrm{S}}$ is the net heat storage in the entire volume above a surface (e.g., urban fabric or plant canopy), and $Q_{\mathrm{A}}$ is the net energy added to or subtracted from a volume due to advection (all in $\mathrm{W} \mathrm{m}^{-2}$ ). In the cases examined here, both $Q_{\mathrm{S}}$ and $Q_{\mathrm{A}}$ are deemed negligible due to judicious site selection, while $Q_{\mathrm{F}}$ is only of relevance at the Vancouver Sunset site, where it is of the order of $20 \mathrm{~W} \mathrm{~m}^{-2}$ (Oke et al., 2017).

The Bowen ratio is defined as $\beta=Q_{\mathrm{H}} / Q_{\mathrm{E}}$ and is a measure of the partitioning of the turbulent heat fluxes. $\beta$ is dependent on availability of water at the surface as well as plant physiology and has important consequences for surface climates by influencing both surface temperature and humidity.

Net ecosystem exchange (NEE in $\mu \mathrm{mol} \mathrm{m}{ }^{-2} \mathrm{~s}^{-1}$ ) is used in quantifying the carbon balance of an ecosystem and is ecosystem respiration $\left(R_{\mathrm{e}}\right)$ minus gross ecosystem photosynthesis (GEP), i.e., NEE $=R_{\mathrm{e}}-$ GEP. NEE is negative when the ecosystem is acting as a $\mathrm{CO}_{2}$ sink and positive when it is acting as a $\mathrm{CO}_{2}$ source.

\section{Results}

\subsection{Satellite, LiDAR, and sunphotometer observations}

MODIS (Moderate Resolution Imaging Spectrometer) imagery for the period is shown in Fig. 2a-d. On 4 July 2015 the region was cloud and smoke free. By 5 July a plume of smoke from the fires in the Elaho valley near Pemberton is evident and extends across the southern and central portion of Vancouver Island (including Buckley Bay but not the three mainland sites). At this time, a "wall of smoke" extended broadly from northwest to southeast along the Strait of Georgia and slightly to the west of the city of Vancouver. This smoke moved across the city of Vancouver at approximately 


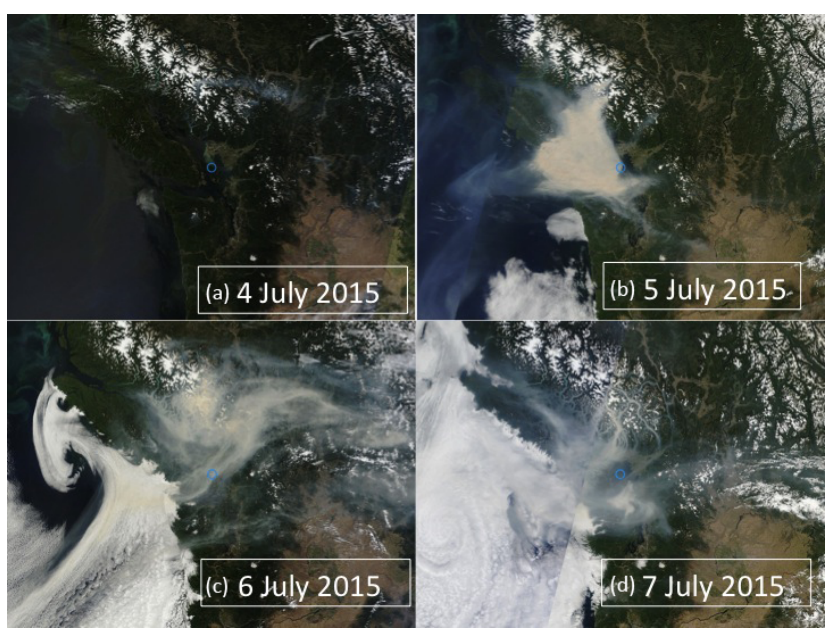

Figure 2. Modis satellite imagery for the period 4-7 July (Saturna Island shown in blue circle).

15:00 Pacific Daylight Time (PDT) on 5 July 2015 (photographic evidence is shown in Supplement). HYSPLIT (Hybrid Single Particle Lagrangian Integrated Trajectory Model) modeling (see Supplement) at this time confirmed the source, shape, and extent of the plume. By 6 July, the plume had dispersed eastward and was accompanied by cloud to the west of Vancouver Island, with a signature consistent with a coastally trapped disturbance (Reason and Dunkley, 1993) or marine "stratus surge" as it is commonly known in the region. However, the region to the east of Vancouver Island remained cloud free and stayed this way during the 6 July when dense smoke was still evident across southwestern British Columbia, including all four of the measurement sites.

The impact of smoke on air quality in the vicinity of Vancouver is shown in Fig. 3. LiDAR imagery (Fig. 3c) shows an elevated layer of smoke over the region at $\sim 2000 \mathrm{~m}$ elevation prior to the arrival of a wall of smoke at ground level at approximately 15:00 PDT on 5 July (depicted by the vertical dashed line). Ground level smoke remained in a shallow layer until approximately 06:00 PDT on 6 July. Subsequently, smoke continued to persist over the region but was confined to a shallow layer at $\sim 1750 \mathrm{~m}$ elevation a.g.l. Smoke again descended toward ground level on 7 July but did not reach the surface. Consequently, $\mathrm{PM}_{10}$ concentrations at Vancouver International Airport (Fig. 3a) peaked (reaching $250 \mathrm{\mu g} \mathrm{m}^{-3}$ ) when smoke was at ground level between 15:00 on 5 July and 06:00 PDT on 6 July. (Note, due to the fact that $\mathrm{PM}_{10}$ is measured with a TEOM instrument and $\mathrm{PM}_{2.5}$ by a Sharp instrument at Vancouver International Airport, differences in instrument principles and calibrations means that under elevated fine-mode particulate matter conditions, $\mathrm{PM}_{2.5}$ values may approach or marginally exceed measured $\mathrm{PM}_{10}$ values, as occurred in this case). Over the entire period there was a modest decrease in daytime maximum and
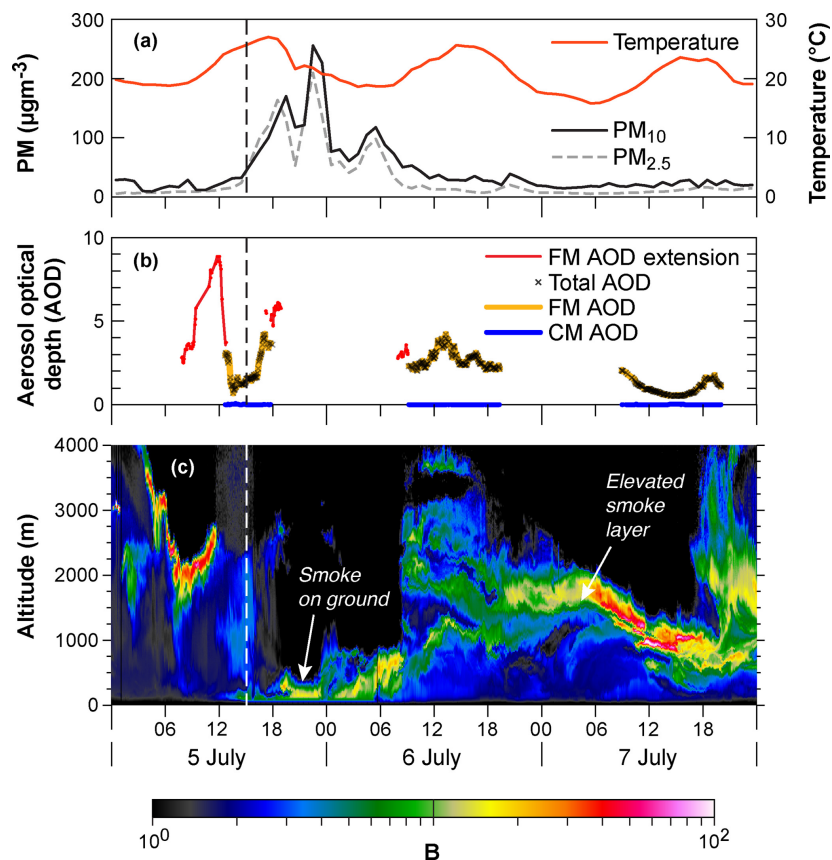

Figure 3. Time series for 5-7 July 2017 showing (a) $\mathrm{PM}_{2.5}$ and $\mathrm{PM}_{10}$ observations and temperature at Vancouver International Airport, and (b) aerosol optical depths for fine-mode (FM) and coarse mode $(\mathrm{CM})$ variation at Saturna Island. The "FM AOD extension" was obtained by assuming that the total AOD at the longer wavelengths of 675 and $870 \mathrm{~nm}$ was dominated by the fine-mode AOD and extrapolating their AODs back to $500 \mathrm{~nm}$ (a choice necessitated by the fact that the extraordinarily large AODs at the shorter wavelengths were eliminated by AERONET processing), and (c) LiDAR backscatter from the UBC CORAL-NET site at $532 \mathrm{~nm}$ for the period. The red vertical line shows arrival of the low-level wall of smoke around 15:00 PDT on 5 July.

minimum temperatures at Vancouver International Airport (Fig. 3a).

Analysis of sunphotometer (Saturna Island), LiDAR (UBC) MODIS, AQUA, and CALIOP (Cloud-Aerosol Lidar with Orthogonal Polarization) together reveal a complex three-dimensional structure associated with the smoke event (with layers extending into the $3-6 \mathrm{~km}$ range a.g.l.). The event, as shown in both LiDAR and CALIOP data consisted of multiple layers with the predominately fine-mode particle signature of smoke confirmed in the AERONET (Saturna Island) data (Fig. 3b). Prior to the arrival of the ground level smoke over Vancouver, fine-mode AOD values at Saturna Island were very high $(\sim 9$ at 11:00 PDT on 5 July) and were (on the basis of detailed analysis of the MODIS and AQUA imagery) likely associated with the higher altitude $(2-3 \mathrm{~km})$ smoke plumes. The 15:00 PDT wall of smoke mentioned above is seen as a sharp fine-mode AOD rise at Saturna following the decay of the strong 11:00 peak of the $2-3 \mathrm{~km}$ layer (a rise that started around 12:30 PDT on 5 July; the $2.5 \mathrm{~h}$ difference being a function of the transport time from Saturna 


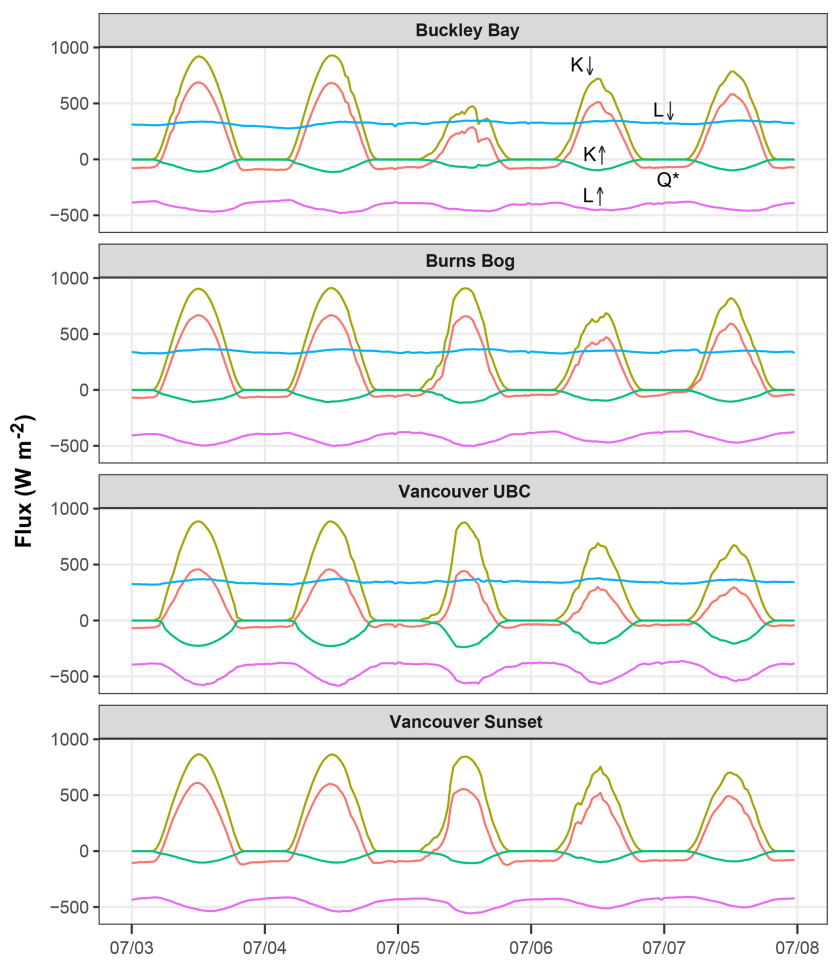

Figure 4. Radiation budget components using standard convention. Fluxes away from surface plotted as negative values.

to UBC, and the time that a significant increase in fine-mode AOD could be detected at Saturna).

\subsection{Impact on radiation and energy budgets}

The course of diurnal radiation budget components at each site is shown in Fig. 4, while daily averages are listed in Table 2. On both 3 and 4 July, all sites show a smooth diurnal course of radiation components consistent with summer clear-sky conditions. On these days, mean daily atmospheric bulk transmissivity $\left(K_{\downarrow} / K_{\text {ext }}\right)$ was approximately $80 \%$ at all sites (Table 2). The most dramatic impact of the smoke plume on radiation components occurred on 5 July at Buckley Bay, when the mean daily transmissivity dropped to $40 \%$ with a reduction in midday $K_{\downarrow}$ of $49 \%$ (to $475 \mathrm{~W} \mathrm{~m}^{-2}$ ) compared to midday values on 3 and 4 July $\left(\sim 920 \mathrm{~W} \mathrm{~m}^{-2}\right)$. This is consistent with satellite imagery (Fig. 2) which shows the smoke layer persisting over Buckley Bay for the entire day on 5 July. At mainland sites, the late arrival of smoke at approximately 15:00 PDT on 5 July is evident in the late afternoon $K_{\downarrow}$ but had less impact on daily totals. Instead, at these mainland sites the biggest impact of the smoke occurred on 6 July, when daily transmissivities dropped to $52 \%-57 \%$ and peak midday $K_{\downarrow}$ values were reduced by approximately $15 \%-25 \%$ compared with those observed on the 3 and 4 July. On this day, LiDAR imagery shows the smoke layer to be at a higher elevation, with less intense backscatter than seen late on 5 July (Fig. 4a).

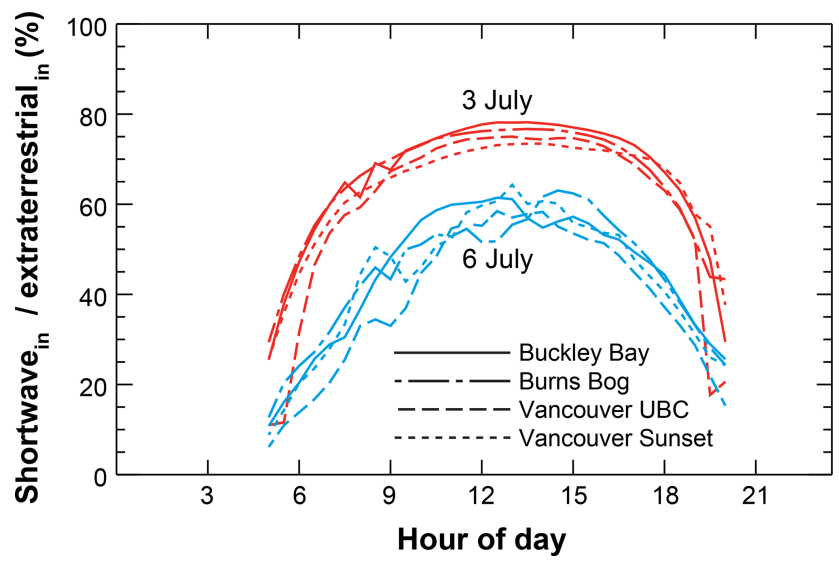

Figure 5. Diurnal impacts on incoming solar radiation at each site for 3 (cloudless day) and 6 (smoke) July.

With respect to remaining radiation budget components, arrival of smoke at all sites was marked by a reduction in $Q^{*}$. However, variations in $L_{\downarrow}$ and $L_{\uparrow}$ were subtle and point to only modest changes in surface or atmospheric temperatures (Fig. 3a). Albedo (Table 2) also increased at the two Vancouver sites as well as the Buckley Bay site with the arrival of smoke and likely is a consequence of the reduction in specular reflection during direct solar irradiance and an increase in diffuse reflection.

Diurnal impacts of the smoke event on atmospheric transmissivity are shown in Fig. 5, where a clear non-smoke day (3 July 2015) is directly compared with 6 July 2015. Of note, the impact of the low-level smoke is apparent in the significant reductions in transmissivity throughout the day. However, near sunrise and sunset, 3 and 6 July have almost the same irradiance at a low sun angle, presumably due to the presence of more diffuse light. Secondly, the impacts are the same across all sites and ecosystems and therefore demonstrate a clear regional signal consistent with the widespread smoke distribution shown in Fig. 2c.

The course of sensible $\left(Q_{\mathrm{H}}\right)$ and latent $\left(Q_{\mathrm{E}}\right)$ turbulent heat fluxes are shown in Fig. 6 and are summarized in Table 2. As with $K_{\downarrow}$ above, the most significant impact on $Q_{\mathrm{H}}$ was at Buckley Bay on 5 July, where it decreased to $18 \%$ (i.e., $41.4 \mathrm{~W} \mathrm{~m}^{-2}$ ) of clear-sky mean daytime time values. At Vancouver Sunset (6 July) and Burns Bog (5 July), the greatest reductions in $Q_{\mathrm{H}}$ were to $52 \%$ and $45 \%$ respectively of the daytime values on the clear-sky days preceding the episode. The impacts on $Q_{\mathrm{E}}$ were less than for $Q_{\mathrm{H}}$ at all sites. At Burns Bog, the minimum for $Q_{\mathrm{E}}$ occurred on 6 July, whereas at Vancouver Sunset, it was on 7 July, and at Buckley Bay, it was on 5 July. At all sites, $\beta$ was significantly reduced on 5 July, with the greatest reduction at Buckley Bay (from $\beta=3.21$ to 0.84 ). The latter was the result of the large reduction in $Q_{\mathrm{H}}$ at that site $(82 \%)$ and the relatively small reduction in $Q_{\mathrm{E}}(32 \%)$. The switch from high direct radiation on 3 and 4 July to predominately diffuse ra- 
Table 2. Daily averages of radiative and turbulent fluxes, Bowen ratio, and carbon dioxide fluxes on 3-7 July for each of the four sites.

\begin{tabular}{|c|c|c|c|c|c|}
\hline & 3 July 2015 & 4 July 2015 & 5 July 2015 & 6 July 2015 & 7 July 2015 \\
\hline \multirow[t]{2}{*}{$K_{\text {ext }}$} & $\mathrm{MJ} \mathrm{m}^{-2}$ day $^{-1}$ & & & & \\
\hline & 37.0 & 36.8 & 36.7 & 36.4 & 36.2 \\
\hline Shortwave $K_{\downarrow}$ & $\mathrm{MJ} \mathrm{m}^{-2}$ day $^{-1}$ & & & & \\
\hline Burns Bog & $29.5(78 \%)^{*}$ & $29.4(78 \%)$ & $25.3(69 \%)$ & $20.8(57 \%)$ & $23.8(65 \%)$ \\
\hline Van. Sunset & $28.3(76 \%)$ & $28.1(76 \%)$ & $23.4(63 \%)$ & $20.8(57 \%)$ & $21.6(60 \%)$ \\
\hline Van. UBC & $28.2(76 \%)$ & $27.8(76 \%)$ & $21.5(59 \%)$ & $18.9(52 \%)$ & $19.7(54 \%)$ \\
\hline Buckley Bay & $29.8(81 \%)$ & $29.9(81 \%)$ & $14.4(39 \%)$ & $21.2(58 \%)$ & $24.4(67 \%)$ \\
\hline \multicolumn{6}{|l|}{$\begin{array}{l}\text { Albedo }(\alpha) \\
K_{\uparrow} / K_{\downarrow}\end{array}$} \\
\hline Burns Bog & 0.18 & 0.18 & 0.18 & 0.18 & 0.17 \\
\hline Van. Sunset & 0.16 & 0.15 & 0.17 & 0.17 & 0.16 \\
\hline Van. UBC & 0.29 & 0.30 & 0.37 & 0.35 & 0.34 \\
\hline Buckley Bay & 0.13 & 0.13 & 0.17 & 0.15 & 0.14 \\
\hline $\begin{array}{l}\text { Sensible heat } \\
Q_{\mathrm{H}}\end{array}$ & $\begin{array}{l}\text { Daytime } \\
\left(\mathrm{W} \mathrm{m}^{-2}\right)\end{array}$ & & & & \\
\hline Burns Bog & 67.3 & 63.4 & 30.5 & 60.0 & 97.6 \\
\hline Van. Sunset & 250.7 & 247.3 & 136.5 & 130.1 & 176.4 \\
\hline Buckley Bay & 232.8 & 217.5 & 41.4 & 136.9 & 179.3 \\
\hline $\begin{array}{l}\text { Latent heat } \\
Q_{\mathrm{E}}\end{array}$ & $\begin{array}{l}\text { Daytime } \\
\left(\mathrm{W} \mathrm{m}^{-2}\right)\end{array}$ & & & & \\
\hline Burns Bog & $116.8(\beta=0.58)$ & $112.8(\beta=0.56)$ & $99.6(\beta=0.31)$ & $89.8(\beta=0.67)$ & $96.4(\beta=1.01)$ \\
\hline Van. Sunset & $53.6(\beta=4.68)$ & $57.8(\beta=4.28)$ & $62.7(\beta=2.18)$ & $48.3(\beta=2.69)$ & $39.0(\beta=4.52)$ \\
\hline Buckley Bay & $72.4(\beta=3.21)$ & $70.1(\beta=3.10)$ & $49.1(\beta=0.84)$ & $60.3(\beta=2.27)$ & $53.5(\beta=3.35)$ \\
\hline $\begin{array}{l}\mathrm{CO}_{2}(\mathrm{NEE}) \\
\text { (daily mean) }\end{array}$ & $\mathrm{gCm}^{-2} \mathrm{day}^{-1}$ & & & & \\
\hline Burns Bog & -1.67 & -1.64 & -2.47 & -3.64 & -4.24 \\
\hline Buckley Bay & 0.16 & 1.26 & 1.13 & -1.35 & -2.31 \\
\hline
\end{tabular}

* percentage of $K_{\mathrm{ext}}$ (extraterrestrial radiation); daytime Bowen ratio $-\beta=Q_{\mathrm{H}} / Q_{\mathrm{E}}$

diation on 5 July was likely responsible for the marked reduction in $Q_{\mathrm{H}}$ as a consequence of reduced heating of leaves in a highly coupled forest canopy (Brümmer et al., 2012). In summary, evapotranspiration was maintained at all sites with the wettest sites (Burns Bog) showing the lowest response to the smoke plume. However, impacts on $Q_{\mathrm{H}}$ were greatest at the forested site (Buckley Bay).

\subsection{Impact on carbon budget and PAR}

Daily values for NEE are shown in Table 2 for two sites (Burns Bog and Buckley Bay) where $\mathrm{CO}_{2}$ fluxes were measured over active vegetation. Throughout the smoke period, Burns Bog remained a net carbon sink and showed an increasingly negative trend in NEE (stronger sink) over the duration of the smoke episode. On 3 July, under clearsky conditions and pre-arrival of smoke the bog was a net $\mathrm{CO}_{2}$ sink $\left(-1.67 \mathrm{~g} \mathrm{C} \mathrm{m}^{-2} \mathrm{day}^{-1}\right)$. This was consis- tent over the seven previous precipitation-free days (mean $-1.69 \mathrm{~g} \mathrm{C} \mathrm{m}^{-2} \mathrm{day}^{-1}$ ). The peak radiative impact of the smoke at Burns Bog occurred on 6 July (albeit somewhat lesser in magnitude than what occurred at Buckley Bay) and was associated with a daily NEE of $-3.64 \mathrm{~g} \mathrm{C} \mathrm{m}^{-2}$ day $^{-1}$ (net sink). This effect was even more pronounced on the following day.

Conversely, at the Buckley Bay forested site, the pre-smoke arrival daily NEE on 3 July showed a $\mathrm{CO}_{2}$ neutral situation $\left(0.16 \mathrm{~g} \mathrm{C} \mathrm{m}^{-2} \mathrm{day}^{-1}\right)$. Again, as with the Burns Bog site, this was consistent with the seven previous precipitation-free days (mean NEE of $-0.08 \mathrm{~g} \mathrm{C} \mathrm{m}^{-2} \mathrm{day}^{-1}$ ), confirming that during such midsummer conditions (clear, warm and precipitation free), the Buckley Bay site at the daily scale is broadly $\mathrm{CO}_{2}$ neutral. On 4 July, prior to smoke arrival, and when the peak reduction on incoming shortwave radiation was felt on 5 July (with sig- 


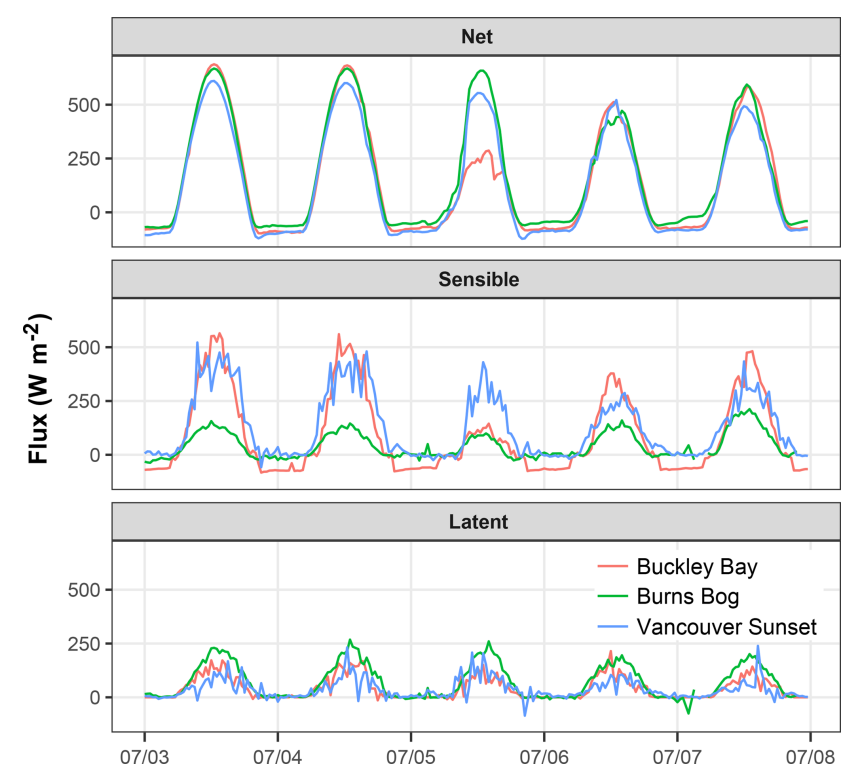

Figure 6. Net radiation $\left(Q^{*}\right)$ and sensible $\left(Q_{\mathrm{H}}\right)$ and latent $\left(Q_{\mathrm{E}}\right)$ heat fluxes at three sites. Fluxes away from surface are plotted as positive values.

nificantly greater solar attenuation than what occurred at the three mainland sites), NEE became more positive (a greater atmospheric source of $\left.\mathrm{CO}_{2}\right)$ and then became a strong net sink on 6 and 7 July $\left(-1.35\right.$ and $-2.31 \mathrm{~g} \mathrm{C} \mathrm{m}^{-2}$ day $^{-1}$ respectively) when the smoke had started to disperse.

Figure 7 shows the course of the PAR $/ K_{\downarrow}$ ratio before and during the smoke episode at Burns Bog. Under clear-sky conditions, PAR is roughly a constant fraction of $K_{\downarrow}$, and for the long-term period and all weather conditions, Tortini et al. (2017) found a value of $1.798 \pm 0.026 \mu \mathrm{mol} \mathrm{J}^{-1}$ for Burns Bog. This value is comparable to the midday values during the first 3 smoke-free days ( 2 to 4 July) of $1789 \mu \mathrm{mol} \mathrm{J}^{-1}$. However, with the arrival of smoke, ratios were reduced significantly to $1.609 \mu \mathrm{mol} \mathrm{J}^{-1}$. This suggests that during heavy smoke, there are fewer PAR photons available for photosynthesis per energy received, although this does not say anything about the ratio of direct to diffuse.

\section{Discussion}

Based on the observations described above, the presence of a dense layer of wildfire smoke near the surface resulted in significant perturbation of both the radiation and energy budgets over a range of surface types in southwestern British Columbia in early July 2015. The effect was most strongly felt at the forested Buckley Bay site on Vancouver Island.

The dramatic attenuation of incoming shortwave radiation described in Sect. 3.2 is entirely consistent with published literature for forest fire plumes described elsewhere and for a similar range of $\mathrm{AOD}_{500}$. Perhaps the best analog is the 2010 fires in central Russia described by Chubarova et al. (2012) and Péré, et al. (2014). Chubarova et al. (2012) report a $40 \%$ loss of shortwave irradiance at $\mathrm{AOD}_{500}=2.5$ (their Fig. 10), a value consistent with the losses of $30 \%-50 \%$ across our four sites (Table 2) in daytime mean fluxes in $K_{\downarrow}$. Interestingly, Chubarova et al. (2012) observed much greater losses of $\sim 65 \%$ for UV radiation $(300-380 \mathrm{~nm})$ and $\sim 80 \%$ for erythemally weighted irradiance. For the same events, Péré et al. (2014) examined the shortwave aerosol direct radiative forcing and its feedback on air and atmospheric temperature over Moscow. For $\tau_{340}$ in the range 2-4, wildfire aerosol caused a significant reduction of surface shortwave radiation (up to $70-84 \mathrm{~W} \mathrm{~m}^{-2}$ in diurnal averages) which is again consistent with the $\sim 100 \mathrm{~W} \mathrm{~m}^{-2}$ reduction over background in diurnal averages of $K_{\downarrow}$ at the four British Columbia sites. While the focus of this paper is the analysis of the impact of a dense smoke event on energy balance and ecosystem $\mathrm{C}$ fluxes, clouds are also known to show similar effects (Park et al., 2018). We found that at the Buckley Bay site for the June-August 2016 period, clouds reduced midday $K_{\downarrow}$ by as much as $90 \%$ relative to the closest clear-sky day, a much greater reduction than with smoke. However, the effects of clouds on ecosystem $\mathrm{C}$ and water fluxes are complicated by the influence of other environmental variables such as wind, temperature, associated precipitation and soil moisture.

Similar agreement is apparent when compared with observed reductions of total solar irradiance by forest fire smoke in the Brazilian Amazon and Zambian savanna (Schafer et al., 2002). At the four sites examined here, total solar irradiance (Table 2) during the fire event represented $50 \%-70 \%$ of background values. This is in broad agreement with the Brazilian sites (Alta Floresta and Abracos Hill) in Schafer et al. (2002; Fig. 1a) which show a reduction of $\sim 68 \%$ for $K_{\downarrow}$ over background values for $\tau_{500}=2.5$. In their study, the African grassland sites show impacts of similar magnitude at somewhat lower AOD values, a likely consequence of the different fuel type, combustion temperatures and aerosol optical properties of the aerosol generated in such fires.

As with radiation budget components, impacts on turbulent heat fluxes were variable across the four sites with the greatest impact at the forested Buckley Bay site where $\beta$ was reduced significantly on 5 July to 0.84 from values of $\sim 3.2$ on the preceding clear days. Again, these results are broadly consistent with prior studies elsewhere showing that the impact of aerosol is reducing $K_{\downarrow}$ (but perhaps increasing diffuse radiation) and hence $Q^{*}, Q_{\mathrm{H}}$, and $Q_{\mathrm{E}}$, with the partitioning of the turbulent fluxes $\beta$ appearing to be ecosystem dependent (Steiner et al., 2013). It is important to note however, that FLUXNET data cited by Steiner et al. (2013) for four forested sites, a grassland site, and a cropland site represent averages from quite different geographical settings than those considered here and are, for $\tau_{500}<1.2$, significantly less than $\tau_{500}$ values observed in this case. 


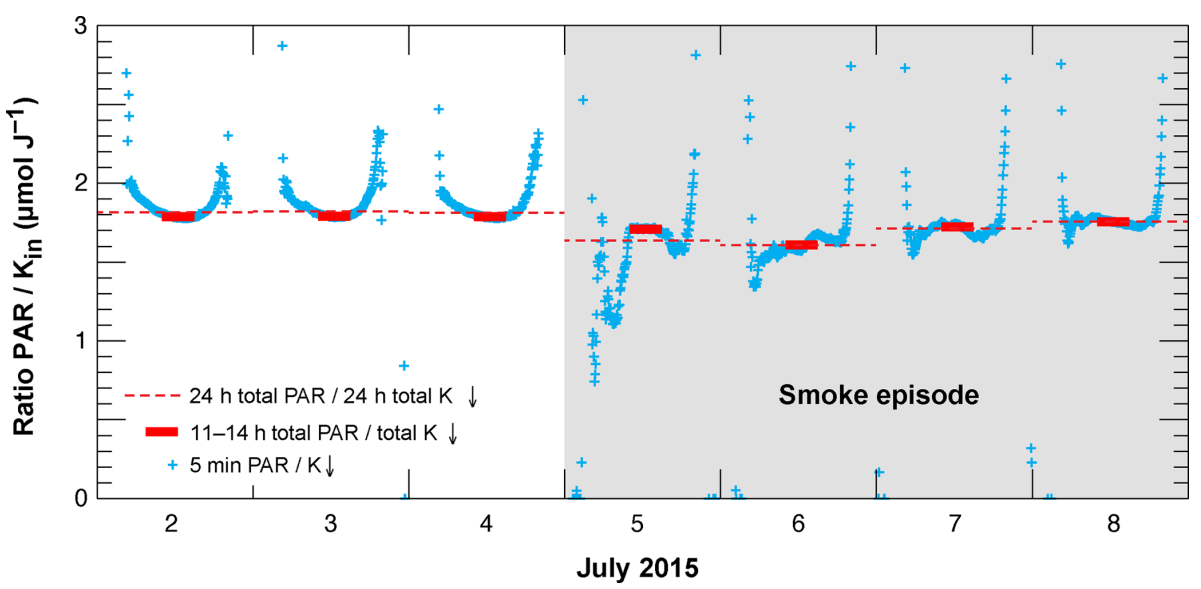

Figure 7. PAR $/ K_{\downarrow}$ ratio at Burns Bog from 2-8 July 2015.

With respect to Buckley Bay observations, where canopy effects are most important, Yamasoe et al. (2006) offer perhaps a more germane comparison in the context of the Amazon rainforest and for smoke AODs of a similar magnitude to those observed at Buckley Bay on 5 July 2015. In their study, both $Q_{\mathrm{H}}$ and $Q_{\mathrm{E}}$ were observed to decrease along with a decrease in PAR due to aerosol attenuation. In this study, Burns Bog offers an interesting contrast to the forested Buckley Bay site. With widespread standing water, and little physiological control on $Q_{\mathrm{E}}$, the impacts on the partitioning of turbulent fluxes were modest compared to the physiologically dominated fluxes at Buckley Bay. The marked reduction in $Q_{\mathrm{H}}$ compared to $Q_{\mathrm{E}}$ (and resulting drop in $\beta$ ) at Buckley Bay clearly shows the dominating effect of canopy (stomatal) resistance over the much smaller aerodynamic resistance in this highly coupled forest ecosystem (McNaughton and Jarvis, 1983).

Whilst the impact of this intense short duration event on radiation and turbulent fluxes of sensible and latent heat are clear cut, the impact on carbon fluxes are less certain. In this case, the short duration, spatial variability in smoke density, and singular nature of the event mitigates against the identification of a clear unambiguous signal. Furthermore, the fact that Buckley Bay was the strongest source of $\mathrm{CO}_{2}$ on 4 July, prior to the arrival of smoke (Table 2), suggests that factors other than smoke aerosol were at play in the observed temporal variability of carbon fluxes. However, this case study offers at least a tentative indication of the potential magnitude of a DRF effect in two quite different ecosystems in the Pacific Northwest. In both cases, the arrival of heavy smoke initiated an apparent ecosystem response. Burns Bog, typically a $\mathrm{CO}_{2}$ sink in clear summer conditions, became an even stronger sink with the arrival of smoke. Buckley Bay forest, generally $\mathrm{CO}_{2}$ neutral in such conditions, became a source with the arrival of heavy smoke and then returned to being a carbon sink on 6 and 7 July when the smoke had started to disperse. The latter hints that as the radiative impact of the smoke diminished, and AOD dropped below the critical threshold of two noted by Yamasoe et al. (2006) and Park et al. (2018), a delayed DRF effect may have been initiated that promoted photosynthesis within the canopy. Further research at both sites under a wide range of smoke events (both duration and intensity) is required.

These broad patterns seem consistent with previous research in different environments (Yamasoe et al., 2006; Nyogi et al., 2004; Park et al., 2018). Yamasoe et al. (2006), in the Amazon basin, show smoke caused an increase in the diffuse fraction of PAR, thereby enhancing transmission deeper into the canopy, leading to enhanced photosynthetic activity and $\mathrm{CO}_{2}$ uptake for moderate $\tau_{500}$. However, of particular relevance to this study, at high $\tau(>2)$, the magnitude of the $\mathrm{CO}_{2}$ flux and NEE decreased, an effect they ascribed to low PAR values and potentially deleterious impacts of pollutants in the smoke itself. This effect has also been observed by Park et al. (2018) in the central Siberian taiga. There, when $\tau>2$, a reduction of PAR and diffuse PAR occurred, and the forest became a $\mathrm{CO}_{2}$ source. The observation in this study that not only is PAR reduced in dense smoke, but also that the ratio of PAR/ $K_{\downarrow}$ is diminished when compared to Tortini et al.'s (2017) typical values, also seems to be an potentially important factor contributing to the overall ecosystem response, especially the magnitude of the DRF effect. We intend to explore this issue (spectral impacts of smoke) further in the context of more recent fire events and, in particular, at the Buckley Bay forested site. It should be noted that the impact of smoke on the radiation budget at Burns Bog was significantly less than what occurred at Buckley Bay (see Table 2). It is therefore likely that the impact on AOD at this site was also diminished (and may not have exceeded $\tau=2$ ) when compared with Buckley Bay. Our results, and those elsewhere, suggest that the ecosystem response to smoke is dependent on the density of smoke and may well be highly variable spatially and temporally and by ecosystem type and canopy architecture. Clearly further research is required in 
western North America to identify the major drivers governing ecosystem response and also the impacts of longer-term exposure to smoke.

Finally, we were unable to quantitatively assess the impact of the smoke layer on atmospheric stability in this case. Elsewhere, it has been shown that dense smoke layers provide a positive feedback mechanism by increasing stability and inhibiting cloud formation. In the absence of a spatial array of vertical soundings and due to the rapidly evolving synoptic situation (where advection was important), we were unable to quantify the radiative effects on the plume layer itself. From available aircraft AMDAR soundings, it was apparent that the plume was trapped by a strong inversion that preceded the arrival of the plume. Certainly, modeling studies in other settings suggest that similar smoke layers may be subject to radiative heating rates of $\sim 6 \mathrm{~K} \mathrm{day}^{-1}$ (Calvo et al., 2010; Feingold et al., 2005; Stone et al., 2008) with significant cooling at the surface, thereby significantly enhancing stability. We propose that a modeling study would help elucidate the processes at play in this case.

\section{Conclusions}

The wildfire smoke episode of early July 2015 in southwestern British Columbia had a significant impact on air quality, the radiation budget, and turbulent fluxes of latent and sensible heat. It also appeared to elicit an ecosystem response with respect to NEE of land ecosystems, although this response depended on the overall concentration, and we observed enhancements and reductions. Across the four land-use types monitored, impacts were variable but were consistent with published literature in other settings. The greatest impacts on radiation and energy budgets were observed at the forested site where the role of canopy architecture, and the complex physiological responses to an increase in diffuse radiation were most important. Despite the short duration and singular nature of the event, there was some evidence of a DRF effect when smoke density was lower than or close to the threshold of $\tau=2$. With lighter smoke, both the wetland and forested site appeared to show enhanced photosynthetic activity (a greater carbon sink). However, with dense smoke, and significantly reduced irradiance, the forested site was a strong source. This is consistent with literature suggesting that with dense smoke, within-canopy PAR is reduced to a point where reduced photosynthetic activity outweighs the DRF effect and the forest becomes a net carbon source (as at night). Given the extensive forest cover in the Pacific Northwest and the growing importance of forest fires in the region, these results suggest that wildfire aerosol potentially plays an important role in the regional ecosystem response to smoke and ultimately the carbon budget of the region. Due to the short duration of the event described here, we recommend further research, including modeling, to elucidate and generalize the patterns observed in this single case.
Data availability. Data from the FLUXNET sites (Ca-Ca3, Ca$\mathrm{DBB}$, and $\mathrm{Ca}-\mathrm{VSu}$ ) are available through the AmeriFlux data repository under http://ameriflux.lbl.gov/ (last access: January 2019).

Supplement. The supplement related to this article is available online at: https://doi.org/10.5194/acp-19-835-2019-supplement.

Author contributions. IGM lead the writing of the paper but all contributed. Flux data were principally collected and provided by AC, $\mathrm{AB}$, and SCL, while LiDAR and sunphotometry data were provided by KBS and NO'N. MF assisted with production of figures.

Competing interests. The authors declare that they have no conflict of interest.

Acknowledgements. We are grateful to the Natural Sciences and Engineering Research Council of Canada (NSERC) for support to individual researchers and graduate students involved in this work. The Burns Bog flux tower operation was funded by Metro Vancouver through contracts to Andreas Christen. Selected instrumentation was supported by NSERC and CFI. The Sunset Tower site was funded by NSERC with in-kind support by BC Hydro, while the University of British Columbia and Environment Canada assisted in various ways to support this research. Eric Leinberger did a wonderful job with the figures, while Rick Ketler and Zoran Nesic provided invaluable field and technical support. We are very grateful for the constructive comments provided by three anonymous reviewers.

Edited by: Markku Kulmala

Reviewed by: three anonymous referees

\section{References}

Bruemmer, C., Black, A., Jassal, R. S., Grant, N. J., Spittlehouse, D. L., Chen, B., Nesic, Z., Amiro, B. D., Arain, M. A., Barr, A. G., Bourque, C., Coursolle, C., Dunn, A. L., Flanagan, L. B., Humphreys, E. R., Lafleur, P. M., Margolis, H. A., McCaughey, J. H., and Wofsy, S. C.: How Climate and Vegetation Type Influence Evapotranspiration and Water Use Efficiency in Canadian Forest, Peatland and Grassland Ecosystems, Agr. Forest Meteorol., 153, 14-30, https://doi.org/10.1016/j.agrformet.2011.04.008, 2012.

Calvo, A. I., Pont, V., Castro, A., Mallet, M., Palencia, C., Roger, J. C., Dubuisson, P., and Fraile, R.: Radiative forcing of haze during a forest fire in Spain, J. Geophys. Res., 115, D08206, https://doi.org/10.1029/2009JD012172, 2010.

Chen, B., Black, T. A., Coops, N. C., Hilker, T., Trofymow, J. A., and Morgenstern, K.: Assessing tower flux footprint climatology and scaling between remotely sensed and eddy covariance measurements, Bound. Layer Meteorol., 130, 137-167, 2009.

Christen, A., Jassal, R., Black, T. A., Grant, N. J., Hawthorne, I., Johnson, M. S., Lee, S.-C., and Merkens, M.: Summer- 
time greenhouse gas fluxes from an urban bog undergoing restoration through rewetting, Mires and Peat, 17, 1-24, 2016.

Chubarova, N., Nezval', Ye., Sviridenkov, I., Smirnov, A., and Slutsker, I.: Smoke aerosol and its radiative effects during extreme fire event over Central Russia in summer 2010, Atmos. Meas. Tech., 5, 557-568, https://doi.org/10.5194/amt-5557-2012, 2012.

Cottle, P., Strawbridge, K., and McKendry, I. : Long-range transport of Siberian wildfire smoke to British Columbia: lidar observations and air quality impacts, Atmos. Environ., 90, 71-77, https://doi.org/10.1016/j.atmosenv.2014.03.005, 2014.

Crawford, B. and Christen, A.: Spatial variability of carbon dioxide in the urban canopy layer and implications for flux measurements, Atmos. Environ., 98, 308-322, 2014.

Feingold, G., Jiang, H., and Harrington, J. Y.: On smoke suppression of clouds in Amazonia, Geophys. Res. Lett., 32, L02804, https://doi.org/10.1029/2004GL021369, 2005.

Holben, B. N., Eck, T. F., Slutsker, I., Tanré, D., Buis, J. P., Setzer, A., Vermote, E., Reagan, J. A., Kaufman, Y. J., Nakajima, T., Lavenu, F., Jankowiak, I., and Smirnov, A.: AERONET - A federated instrument network and data archive for aerosol characterization, Remote Sens. Environ., 66, 1-16, https://doi.org/10.1016/S0034-4257(98)00031-5, 1998.

Humphreys, E. R., Black, T. A., Morgenstern, K., Cai, T., Drewitt, G. B., Nesic, Z., and Trofymow, J. A.: Carbon dioxide fluxes in coastal Douglas-fir stands at different stages of development after clearcut harvesting, Agr. Forest Meteorol., 140, 6-22, 2006.

IPCC: Climate Change 2014: Impacts, Adaptation, and Vulnerability. Part B: Regional Aspects. Contribution of Working Group II to the Fifth Assessment Report of the Intergovernmental Panel on Climate Change, edited by: Barros, V. R., Field, C. B., Dokken, D. J., Mastrandrea, M. D., Mach, K. J., Bilir, T. E., Chatterjee, M., Ebi, K. L., Estrada, Y. O., Genova, R. C., Girma, B., Kissel, E. S., Levy, A. N., MacCracken, S., Mastrandrea, P. R., and White, L. L., Cambridge University Press, Cambridge, United Kingdom and New York, NY, USA, pp. 688, 2014.

Kanniah, K. D., Beringer, J., and Hutley, L. B.: The comparative role of key environmental factors in determining savanna productivity and carbon fluxes: A review, with special reference to northern Australia, Prog. Phys. Geogr., 34, 459-490, 2010.

Lee, S.-C., Christen, A., Black, A. T., Johnson, M. S., Jassal, R. S., Ketler, R., Nesic, Z., and Merkens, M.: Annual greenhouse gas budget for a bog ecosystem undergoing restoration by rewetting, Biogeosciences, 14, 2799-2814, https://doi.org/10.5194/bg-142799-2017, 2017.

Li, F., Lawrence, D. M., and Bond-Lamberty, B.: Impact of fire on global land surface air temperature and energy budget for the 20th century due to changes within ecosystems, Environ. Res. Lett., 12, https://doi.org/10.1088/1748-9326/aa6685, 2017.

Markowicz, K. M., Lisok, J., and Xian, P.: Simulations of the effect of intensive biomass burning in July 2015 on Arctic radiative budget, Atmos. Environ., 171, 248-260, https://doi.org/10.1016/j.atmosenv.2017.10.015, 2017.

McKendry, I. G.: Synoptic circulation and summertime groundlevel ozone concentrations in Vancouver, British Columbia, J. Appl. Meteorol., 33, 627-641, 1994.

McKendry, I. G., Gallagher, J., Campuzano Jost, P., Bertram, A., Strawbridge, K., Leaitch, R., and Macdonald, A. M.: Ground-based remote sensing of an elevated forest fire aerosol layer at Whistler, BC: implications for interpretation of mountaintop chemistry, Atmos. Chem. Phys., 10, 11921-11930, https://doi.org/10.5194/acp-10-11921-2010, 2010.

McKendry, I., Strawbridge, K., Karumudi, M. L., O’Neill, N., Macdonald, A. M., Leaitch, R., Jaffe, D., Cottle, P., Sharma, S., Sheridan, P., and Ogren, J.: Californian forest fire plumes over Southwestern British Columbia: lidar, sunphotometry, and mountaintop chemistry observations, Atmos. Chem. Phys., 11, 465-477, https://doi.org/10.5194/acp-11-465-2011, 2011.

McNaughton, K. G. and Jarvis, P. G.: Predicting effects of vegetation changes on transpiration and evaporation, in: Water Deficit and Plant Growth, edited by: Koslowski, T. T., Academic Press, New York, 7, 1-47, 1983.

Moreira, D. S., Longo, K. M., Freitas, S. R., Yamasoe, M. A., Mercado, L. M., Rosário, N. E., Gloor, E., Viana, R. S. M., Miller, J. B., Gatti, L. V., Wiedemann, K. T., Domingues, L. K. G., and Correia, C. C. S.: Modeling the radiative effects of biomass burning aerosols on carbon fluxes in the Amazon region, Atmos. Chem. Phys., 17, 14785-14810, https://doi.org/10.5194/acp-1714785-2017, 2017.

Niyogi, D., Chang, H., Saxena, V. K., Holt, T. R., Alapaty, K., Booker, F., Chen, F., Davis, K. J., Holben, B., Matsui, T., Meyers, T., Oechel, W. C., Pielke, R. A., Wells, R., Wilson, K. V., and Xue, Y.: Direct observations of the effects of aerosol loading on net ecosystem $\mathrm{CO}_{2}$ exchanges over different landscapes, Geophys. Res. Lett., 31, L20506, https://doi.org/10.1029/2004GL020915, 2004.

Oke, T. R.: Boundary Layer Climates, 2nd Edition, Methuen Co., London, New York, 435 pp., 1987.

Oke, T. R., Mills, G., Christen, A., and Voogt, J. A.: Urban Climates, Cambridge University Press, 525 pp., 2017.

Park, S.-B., Knohl, A., Lucas-Moffat, A. M., Migliavacca, M., Gerbig, C., Vesala, T., Peltola, O., Mammarella, I., Kolle, O., Lavric, J. V., Prokushkin, A., and Heimann, M.: Strong radiative effect induced by clouds and smoke on forest net ecosystem productivity in central Siberia, Agr. Forest Meteorol., 250-251, 376-387, https://doi.org/10.1016/j.agrformet.2017.09.009, 2018.

Péré, J. C., Bessagnet, B., Mallet, M., Waquet, F., Chiapello, I., Minvielle, F., Pont, V., and Menut, L.: Direct radiative effect of the Russian wildfires and its impact on air temperature and atmospheric dynamics during August 2010, Atmos. Chem. Phys., 14, 1999-2013, https://doi.org/10.5194/acp-14-1999-2014, 2014.

Reason, C. J. C. and Dunkley, R.: Coastally trapped stratus events in British Columbia, Atmos.-Ocean, 31, 235-258, https://doi.org/10.1080/07055900.1993.9649470, 1993.

Schafer, J. S., Eck, T. F., Holben, B. N., Artaxo, P., Yamasoe, M. A., and Procopio, S.: Observed reductions of total solar irradiance by biomass-burning aerosols in the Brazilian Amazon and Zambian Savanna, Geophys. Res. Lett., 29, 1823, https://doi.org/10.1029/2001GL014309, 2002.

Sena, E. T., Artaxo, P., and Correia, A. L.: Spatial variability of the direct radiative forcing of biomass burning aerosols and the effects of land use change in Amazonia, Atmos. Chem. Phys., 13, 1261-1275, https://doi.org/10.5194/acp-13-1261-2013, 2013.

Settele, J., Scholes, R., Betts, R., Bunn, S., Leadley, P., Nepstad, D., Overpeck, J. T., and Taboada, M. A.: Terrestrial and inland water systems, in: Climate Change 2014: Impacts, Adaptation, and Vulnerability. Part A: Global and Sectoral Aspects. Contribution of Working Group II to the Fifth Assessment Report of the In- 
tergovernmental Panel on Climate Change, edited by: Field, C. B., Barros, V. R., Dokken, D. J., Mach, K. J., Mastrandrea, M. D., Bilir, T. E., Chatterjee, M., Ebi, K. L., Estrada, Y. O., Genova, R. C., Girma, B., Kissel, E. S., Levy, A. N., MacCracken, S., Mastrandrea, P. R., and White, L. L., Cambridge University Press, Cambridge, United Kingdom and New York, NY, USA, 271-359, 2014.

Steiner, A. L., Mermelstein, D., Cheng, S. J., Twine, T. E., and Oliphant, A.: Observed impact of atmospheric aerosols on the surface energy budget, Earth Interact., 17, 1-22, https://doi.org/10.1175/2013EI000523.1, 2013.

Stone, R. S., Anderson, G. P., Shettle, E. P., Andrews, E., Loukachine, K., Dutton, E. G., Schaaf, C., and Roman III, M. O.: Radiative impact of boreal smoke in the Arctic: Observed and modeled, J. Geophys. Res., 113, D14S16, https://doi.org/10.1029/2007JD009657, 2008.

Strawbridge, K. B.: Developing a portable, autonomous aerosol backscatter lidar for network or remote operations, Atmos. Meas. Tech., 6, 801-816, https://doi.org/10.5194/amt-6-8012013, 2013.

Taubman, B. F., Marufu, L. T., Vant-Hull, B. L., Piety, C. A., Doddridge, B. G., Dickerson, R. R., and Li, Z.: Smoke over haze: Aircraft observations of chemical and optical properties and the effects on heating rates and stability, J. Geophys. Res., 109, D02206, https://doi.org/10.1029/2003JD003898, 2004.

Tortini, R., Coops, N. C., Nesic, Z., Christen, A., Lee, S. C., and Hilker, T.: Remote sensing of seasonal light use efficiency in temperate bog ecosystems, Scientific Reports, 7, 8563, https://doi.org/10.1038/s41598-017-08102-x, 2017.
Vant-Hull, B., Li, Z., Taubman, B. F., Levy, R., Marufu, L., Chang, F.-L., Doddridge, B. G., and Dickerson, R. R.: Smoke over haze: Comparative analysis of satellite, surface radiometer, and airborne in situ measurements of aerosol optical properties and radiative forcing over the eastern United States, J. Geophys. Res., 110, D10S21, https://doi.org/10.1029/2004JD004518, 2005.

Wang, J. and Christopher, S. A.: Mesoscale modeling of Central American smoke transport to the United States: 2. Smoke radiative impact on regional surface energy budget and boundary layer evolution, J. Geophys. Res., 111, D14S92, https://doi.org/10.1029/2005JD006720, 2006.

Wang, S.-H., Lin, N.-H., Chou, M.-D., and Woo, J.-H.: Estimate of radiative forcing of Asian biomass-burning aerosols during the period of TRACE-P, J. Geophys. Res., 112, D10222, https://doi.org/10.1029/2006JD007564, 2007.

Webb, E. K., Pearman, G. I., and Leuning, R.: Correction of Flux Measurements for Density Effects Due to Heat and Water Vapour Transfer, Q. J. Roy. Meteorol. Soc., 106, 85-100, 1980.

Yamasoe, M. A., von Randow, C., Manzi, A. O., Schafer, J. S., Eck, T. F., and Holben, B. N.: Effect of smoke and clouds on the transmissivity of photosynthetically active radiation inside the canopy, Atmos. Chem. Phys., 6, 1645-1656, https://doi.org/10.5194/acp-6-1645-2006, 2006. 